\title{
Endothelial progenitor cells: what use for the cardiologist?
}

\author{
Journal of Angiogenesis Research 2:6 I DOI: 10.1186/2040-2384-2-6 I C Li et al.; licensee Publiverse Online \\ S.R.L. 2010 \\ Received: 8 Dec 2009 | Accepted: 22 Dec 2010 | Published: 22 Dec 2010 \\ Siddique Aurangzeb ${ }^{+}$, Shantsila Eduard ${ }^{+}$, Lip Gregory YH ${ }^{@}$, Varma Chetan \\ ${ }^{+}$Contributed equally ${ }^{\circledR}$ Corresponding author
}

\begin{abstract}
Endothelial Progenitor Cells (EPC) were first described in 1997 and have since been the subject of numerous investigative studies exploring the potential of these cells in the process of cardiovascular damage and repair. Whilst their exact definition and mechanism of action remains unclear, they are directly influenced by different cardiovascular risk factors and have a definite role to play in defining cardiovascular risk. Furthermore, EPCs may have important therapeutic implications and further understanding of their pathophysiology has enabled us to explore new possibilities in the management of cardiovascular disease. This review article aims to provide an overview of the vast literature on EPCs in relation to clinical cardiology.
\end{abstract}

\section{Introduction}

Maintenance of endothelial integrity and functioning is vital to the preservation of a healthy vasculature [1]. Thus, the impairment as well as insufficient recovery potential of the endothelial cell monolayer is believed to be a critical factor during the initiaton and progression of atherosclerosis [ 2]. Indeed, endothelial damage/dysfunction has been proved to be involved in the pathogenesis of atherothrombotic vascular disease, with important prognostic and therapeutic implications.

Although the possibility that adult endothelial precursors may exist was suggested more than four decades ago, Asahara et al. first reported isolation of putative adult endothelial precursors which we now recognize as endothelial progenitor cells (EPCs), only in 1997 [ 3,4]. Endothelial progenitors were able to differentiate into mature endothelial cells and promote repair of damaged endothelium [ 5-8]. Progressively increasing number of studies has been devoted to these enigmatic cells in the recent years and their close association with multiple markers of cardiovascular health is now well-recognised.

Apart from a diagnostic and prognostic role, EPCs may be attractive target for treatment and, at the same time, be used themselves in an attempt to stimulate angiogenesis, vasculogenesis and cardiac performance. As an example, CD34 antibody coated stents designed to attract EPCs to the healing endothelium are under intensive clinical trial investigation. However, the precise role of EPCs in vascular pathology still needs to be further clarified as results of some currently available studies in the literature are controversial.This article aims to provide an overview of the vast literature on EPCs in relation to clinical cardiology.

\section{EPCs ageing and physical activity}

Physiological factors and conventional risk factors for atherosclerosis are associated with variations of the number and activity of endothelial progenitors and may be the bridge linking EPCs to common cardiovascular disorders such as coronary artery disease $(\mathrm{CAD})$, myocardial infarction and heart failure.

EPC characteristics are closely associated with the presence of various cardiovascular risk factors (Table 1). EPC numbers or function - or both - may be affected. For example, smoking contributes towards reducing the number of circulating EPCs, whilst hypertension reduces migratory capacity [9]. Serum LDL cholesterol levels, a positive family history of CAD, and age have all been shown to influence the number and migration of circulating CD34 + cells and EPCs [9].

Table 1

Cardiovascular risk

factors 


\begin{tabular}{|c|c|c|c|}
\hline Hypercholesterolemia & $\begin{array}{l}\text { Reduced EPC number, impaired EPC } \\
\text { migratory capacity }\end{array}$ & $\begin{array}{l}\text { Circulating EPCs (CD133, 34, } \\
\text { 45) CFU-ECs }\end{array}$ & {$[9,23]$} \\
\hline Diabetes Mellitus & $\begin{array}{l}\text { Reduced EPC number, impaired EPC } \\
\text { migratory capacity }\end{array}$ & $\begin{array}{l}\text { Circulating EPCs (CD31, 34, } \\
\text { KDR) CFU-ECs }\end{array}$ & $\begin{array}{l}{[26,27,} \\
29,30]\end{array}$ \\
\hline Hypertension & $\begin{array}{l}\text { Inverse relationship of EPC number with } \\
\text { systolic blood pressure }\end{array}$ & $\begin{array}{l}\text { Circulating EPCs (CD133, } 34, \\
\text { KDR) }\end{array}$ & {$[9,34]$} \\
\hline Smoking & $\begin{array}{l}\text { Affects EPC number in a dose-dependent } \\
\text { manner }\end{array}$ & $\begin{array}{l}\text { Circulating EPCs (CD133, 34, } \\
\text { KDR) CFU-ECs }\end{array}$ & {$[35,36]$} \\
\hline Ageing & Reduced migration and proliferation & $\begin{array}{l}\text { Circulating EPCs (CD133, 34, } \\
\text { 45) CFU-ECs }\end{array}$ & $\begin{array}{l}{[10-14,} \\
113]\end{array}$ \\
\hline Exercise & Increased EPC number and function & $\begin{array}{l}\text { Circulating EPCs (CD133, } 34 \text {, } \\
45) \text { CFU-ECs }\end{array}$ & $\begin{array}{l}{[15,17-} \\
20]\end{array}$ \\
\hline
\end{tabular}

EPC - endothelial progenitor cells

Effects of cardiovascular risk factors on EPC number and function

There is an age-related quantitative decline in bone marrow cells expressing endothelial progenitor markers [ 3]. Jie et al analysed the number of circulating $\mathrm{CD} 34^{+} / \mathrm{KDR}^{+} \mathrm{EPCs}$ in healthy subjects aged from 1 to 81 years old, and an inverse relationship with age was observed [ 10]. The progressive reduction in different progenitor cell populations with age was also confirmed by Shaffer et al, both in healthy donors and in patients with peripheral arterial disease [ 11]. Impairment of the functional activity of endothelial progenitors also parallels downregulation of their numbers [ 12]. This decline in EPC clonogenic capacity appears to occur at an earlier age, followed by a decline in migratory activity.

Admittedly, some controversy still exists on the relationship of age to EPC levels. For example, Pelliccia et al failed to find any difference in absolute numbers of CD34+, CD133 ${ }^{+}, \mathrm{CD} 105^{+}$, and $\mathrm{CD} 14^{+}$cells in older patients with $\mathrm{CAD}$ indicating a strong impact of factors other than age for the presence in atherosclerosis and re-emphasising the necessity of having a precise definition of EPC populations studied [ 13]. The decrease in EPC recruitment in the elderly may be associated with downregulation of tissue hypoxia-inducible factor 1 or insufficient local expression of VEGF, one of the key attractors of EPCs [ 14]. Furthermore, over an individual's lifetime, long-lived cells such as bone marrow endothelial precursors incur repeated exposures to oxidative stress; initially, EPCs may compensate by increasing their antioxidant responses to prevent oxidant injury. Over time, oxidant damage is likely to accumulate, thus diminishing the functional properties of EPCs.

Physical activity effectively promotes EPC health in terms of quantity, functional capacity and the prevention of apoptosis [ 15]. This effect is rapid and sustained, at least for 4 weeks [15]. Importantly, physical activity positively affects both bone marrow and peripheral EPC levels [ 15]. Furthermore, studies in animals have shown that physical activity enhances replacement of the dysfunctional endothelium by bone marrow-derived cells [ 16].

A rapid increase of EPC numbers following physical exertion may be attributable to acute mobilisation of the bone marrow EPC pool or a shear stress-induced release into circulation of vessel-wall resident EPCs [ 17, 18]. Again, NO-dependent mechanisms may by involved, given that physical exercise increases NO bioavailability [ 19]. The effect of physical activity on EPCs may be reduced by inhibition of endogenous NO synthase [20].

\section{EPCs and cardiovascular risk factors}

Hypercholesterolemia negatively affects both EPC number and function. Indeed, EPC count has an inverse relationship with total cholesterol and LDL-cholesterol levels [9]. Enhanced oxidative stress associated with dyslipidaemia may at least be partly involved in the dysregulation of EPC mobilisation, maturation and survival. Of note, circulating EPCs are very sensitive to oxidized LDL, resulting in premature apoptosis [ 21, 22]. Enhanced endothelial dysfunction and damage may result in higher tissue demand for EPCs and their increased turnover. Hypercholesterolaemia may also directly affect the bone marrow, resulting in depletion or exhaustion of the bone marrow pool of endothelial progenitors, with a consequent limited supply of EPCs released into circulation [ 23]. Also, LDL cholesterol levels have an inverse relation with EPC migratory capacity [ 23]. Elevated LDL cholesterol and oxidized LDL levels impair EPC migration, via a VEGF-mediated pathway, and oxidized LDL blocks VEGF-induced EPC migration through the inhibition of NO production [ 24, 25].

Reduced levels of EPCs have been described in both type 1 and type 2 diabetes mellitus [ 26]. EPC recruitment for re-endothelialization after vascular injury is impaired in patients with diabetes, and as a consequence of such EPC dysfunction, the vascular regenerative potential of this disease group may be reduced - thus, contributing to the development of vascular complications [27]. Indeed, decreased numbers and functional activity of early EPCs are significantly associated with the pathogenesis of vascular complications in either type 1 or type 2 diabetes [ 26, 27]. Hyperglycemia significantly reduces eNOS production by EPCs with a corresponding decline in nitric oxide (NO) bioavailability [ 31]. The effects of high glucose could be ameliorated by co-incubation of EPCs with the NO donor sodium nitroprusside or p38 mitogen-activated protein kinase inhibitor, and deteriorated by eNOS inhibitor [ 28]. In contrast, antioxidants including vitamin $\mathrm{C}, \mathrm{N}$-acetylcysteine and polyethylene glycol-conjugated superoxide dismutase, and polyethylene glycol-catalase have no significant effects on EPCs [ 28]. This suggests that the inhibitory effects of high glucose on EPC could be reversed by NO donors, but not by various antioxidants. 
Systolic blood pressure has a negative correlation with the number of circulating EPCs, but the clonogenic potential (number of CFU-ECs) is not impaired by arterial hypertension [ 9]. Angiotensin II accelerates the onset of EPC senescence, leading to impaired proliferation of EPCs; this seems to be inhibited by treatment with the angiotensin II type 1 receptor blocker, valsartan [ 29]. Ramipril also improves the proliferation and migration of EPCs, as well as in vitro vasculogenesis in patients with CAD [30].

These observations were confirmed in the Endothelial Progenitor Cells in Coronary Artery Disease (EPCAD) study, demonstrating that angiotensin-converting enzyme inhibitor treatment was associated with increased numbers and improved clonogenic potential of circulating EPCs, when compared with patients who were not taking angiotensinconverting enzyme inhibitors [31].

Whilst smoking leads to a reduction in EPC counts, nicotine itself may have a positive effect on EPC numbers and functional activity at low concentrations [ 32,33]. This is supported by the finding that the use of nicotine patches slightly increases the magnitude of the rise in EPC levels after smoking cessation [32]. However, higher nicotine levels will have cytotoxic effects on EPCs, indicating complex effects of nicotine on EPCs [ 33]. Indeed, the number of EPCs is reduced in chronic smokers, whilst cessation of smoking leads to rapid restoration of EPC levels [ 32]. In contrast, smoking cessation leads to rapid recovery of the circulating EPC population, especially amongst light smokers [ 32].

Recent studies have established a clear link between levels of circulating EPCs and the cumulative cardiovascular risk profile [ 8]. For example, Hill et al[ 8] hypothesized that EPCs derived from the bone marrow have a role in ongoing endothelial repair and thus, the depletion of these cells contributes to cardiovascular disease progression. Also, the number of CFU-EC colonies from peripheral blood correlates closely with endothelial function. Thus, EPC levels could be used as a 'biological marker' (or biomarker) for vascular function and the relationship to cumulative cardiovascular risk.

Although mechanisms linking cardiovascular risk factors and the impairment of EPC mobilization and function are not sufficiently well understood, the number of studies strongly indicates that chronic inflammation and oxidative stress may play a critical role, despite substantial resistance of endothelial progenitors to oxidative burden [ 34-36].

\section{EPCs and cardiovascular pathology}

\section{Therapeutic modification of EPCs}

\section{Transplantation of EPCs}

The available data that demonstrate angiogenic properties of EPCs and favorable outcomes of animal studies have encouraged clinical trials in patients with ischemic heart disease, particularly in the AMI setting [ 94]. However, results of human studies have proved to be controversial with some trials reporting significant improvement in cardiac vascularisation and performance while others failing to show any benefits. Results of randomized clinical studies are on cardiac transplantation of cells with endothelial progenitor potential are summarized in table 4 .

Table 4

\begin{tabular}{|c|c|c|c|c|c|c|}
\hline Study/year & Disorder & $\mathbf{N}$ & Delivery route & $\begin{array}{l}\text { Cells } \\
\text { delivered }\end{array}$ & $\begin{array}{l}\text { Follow- } \\
\text { up } \\
\text { (months) }\end{array}$ & Effectiveness \\
\hline Strauer et al. (2002) [ 117] & AMI & 20 & Intracoronary & BM-MNCs & 4 & Effective \\
\hline $\begin{array}{l}\text { Kang et al. MAGIC (2004) [ } \\
\text { 92] }\end{array}$ & $\begin{array}{l}\text { AMI Old } \\
\text { MI }\end{array}$ & 27 & Intracoronary & $\begin{array}{l}\text { PB-MNCs } \\
\text { and G-CSF }\end{array}$ & 6 & $\begin{array}{l}\text { Effective, but high } \\
\text { rate of in-stent re- } \\
\text { stenosis }\end{array}$ \\
\hline $\begin{array}{l}\text { Schachinger et al. TOPCARE- } \\
\text { AMI (2004) [ 118] }\end{array}$ & AMI & 59 & Intracoronary & $\begin{array}{l}\text { PB-MNCs } \\
\text { or BM- } \\
\text { MNCs }\end{array}$ & 12 & Effective \\
\hline Ruan et al. (2005) [ 119] & Acute MI & 20 & Intracoronary & BM-MNCs & 6 & Effective \\
\hline $\begin{array}{l}\text { Strauer et al. IACT (2005) [ } \\
\text { 120] }\end{array}$ & $\begin{array}{l}\text { Chronic } \\
\text { CAD }\end{array}$ & 36 & Intracoronary & BM-MNCs & 3 & Effective \\
\hline Bartunek et al. (2005) [ 111] & $\begin{array}{l}\text { Recent } \\
\text { MI }\end{array}$ & 35 & Intracoronary & CD133+ & 4 & Effective \\
\hline Erbs et al. (2005) [ 112] & $\begin{array}{l}\text { Chronic } \\
\text { CAD }\end{array}$ & 26 & Intracoronary & $\begin{array}{l}\text { Cultured } \\
\text { PB-EPCs }\end{array}$ & 3 & Effective \\
\hline Assmus et al. (2006) [ 111] & $\begin{array}{l}\text { Chronic } \\
\text { CAD }\end{array}$ & 53 & Intracoronary & BM-MNCs & 3 & Effective \\
\hline $\begin{array}{l}\text { Meyer et al. BOOST (2006) [ } \\
\text { 104] }\end{array}$ & Acute MI & 60 & Intracoronary & BM-MNCs & 18 & $\begin{array}{l}\text { Effective at } 6 \text { month, } \\
\text { ineffective at } 18 \\
\text { month }\end{array}$ \\
\hline Hendrikx et al. (2006) [ 121] & $\begin{array}{l}\text { Heart } \\
\text { failure }\end{array}$ & 20 & Intramyocardial & BM-MNCs & 4 & Ineffective \\
\hline
\end{tabular}




\begin{tabular}{l|l|l|l|l|l|l}
\hline Study/year & Disorder & N & Delivery route & $\begin{array}{l}\text { Cells } \\
\text { delivered }\end{array}$ & $\begin{array}{l}\text { Follow- } \\
\text { up } \\
\text { (months) }\end{array}$ & Effectiveness \\
\hline $\begin{array}{l}\text { Janssens et al. (2006) [ 105] } \\
\begin{array}{l}\text { Kang et al. MAGIC Cell-3- } \\
\text { DES (2006) [ 60] }\end{array}\end{array}$ & $\begin{array}{l}\text { Acute MI } \\
\text { Old MI }\end{array}$ & 82 & Intracoronary & $\begin{array}{l}\text { BM-MNCs } \\
\text { In-MNCs }\end{array}$ & 4 & Ineffective \\
$\begin{array}{l}\text { Schachinger et al. REPAIR- } \\
\text { AMI (2006) [ 106, 122] }\end{array}$ & AMI & 201 & Intracoronary & BM-MNCs & 12 & Effective \\
$\begin{array}{l}\text { Ge et al. TCT-STAMI (2006) [ } \\
\text { 95] }\end{array}$ & MI & 20 & Intracoronary & BM-MNCs & 6 & Effective \\
Meluzin et al. (2007) [ 122] & Acute MI & 60 & Intracoronary & BM-MNCs & 12 & Effective \\
\hline
\end{tabular}

AMI - acute myocardial infarction, BM - bone marrow, CAD - coronary artery disease, G-CSF - granulocyte-colony stimulating factor, MI - myocardial infarction, MNC - mononuclear cell, PB - peripheral blood.

\section{Randomized clinical studies on transplantation of cells which include endothelial progenitors}

The majority of completed randomized trials have demonstrated some benefits of stem cells treatment, and studies uniformly report the safety of this approach with no specific adverse events observed (including proarrhythmia, oncology or excessive inflammatory burden)[ 95, 96]. High rate of in-stent restenosis in the MAGIC study where cell therapy was combined with G-CSF administration has been discussed above [ 59]. In the BOOST trial, intracoronary implantation of bone marrow cells did not provide long-term benefit on left ventricular systolic function after AMI compared to a randomized control group; however, stem cell therapy was associated with acceleration of left ventricular recovery [97].

In the study by Janssens et al [ 98], transfer of bone marrow stem cells to the coronary artery in 67 patients with AMI did not contributed to improvement of the global left ventricular function, but did favorably affected infarct remodelling at 4 months follow-up, with a reduction in infarct size. In the double-blind, placebo-controlled multicentre REPAIR-AMI trial, 204 patients with MI were randomized to bone marrow-derived cells or placebo [ 99]. At 12 months, the pre-specified cumulative endpoint of death, myocardial infarction, or necessity for revascularization was significantly reduced in the stem cell-therapy group compared with placebo; of note, stem cells therapy was an independent predictor of a favorable clinical outcome in this study [99].

Alternative to intracoronary infusion routs of stem cell delivery such as intramyocardial implantation (either during cardiac surgery on NOGA system) have also been tested [ 100, 101]. In the only randomised with percutaneous transendocardial injections of CD34+ cells to patient with severe intractable angina, this method was found to be feasible and safe and is being extended into a larger ongoing phase IIb study [ 102].

Given the controversy of trial results, important issues have arisen about the factors affecting the efficacy of such therapy. In addition to route of administration, the time of stem cell delivery (ie. after AMI), origin and number of cells used may be critical. In fact, the majority of studies have used unselected mononuclear cells with unknown but evidently very low proportion of endothelial progenitors but with progenitors of other origins (eg. mesenchimal stem cells), this could be potentially favorable for cardiac recovery. Indeed, when either bone marrow or circulating mononuclear cells were delivered to infarct-related coronary arteries, treatment with bone morrow cells resulted in a better improvement of left ventricular contractility, when compared to peripheral blood cells [ 103]. Several studies with selected CD34+, CD133+ cells or cultured peripheral blood EPCs have been successfully performed but large controlled studies are required to evaluate their clinical utility [ 102, 104, 105].

Although different factors may impair EPCs-mediated vascular repair (for example, abnormality in their mobilisation from bone marrow and homing to the damaged vascular tissues, and exhaustion of their bone marrow niche), the available data strongly indicate functional characteristics of circulating endothelial progenitors are relevant. Accordingly, appropriate genetic modification of EPCs before their implantation may be a way to improve their angiogenic potential. The feasibility of this approach has been demonstrated by genetic inhibition of glycogen synthase kinase- $3 \beta$ signaling in human EPCs that was associated with significant enhancement of their angiogenic properties in an animal model of ischaemia [ 106]. Additionally, the angiogenic potential of EPCs can be improved by non-genetic ex-vivo stimulus (for example, by exposure to hypoxia). However, the clinical relevance of these approaches needs further investigation [ 107].

\section{Understanding of EPCs - where we are now?}

Despite more that a decade of very intensive research and many studies devoted to the problem of understanding EPC biology, their potential clinical role is still largely limited by lack of a consensus on the phenotypic and functional definition of endothelial precursors [ 108]. At present, a single term 'EPC' refers to a very diverse group of cells of different lineages which appear to have some angiogenic potential, but not necessarily the ability to differentiate into functional endothelial cells, as expected from their name. Accordingly, a booming number of new publications on 'EPCs' may have limited scientific impact without a clear understanding what type of cell is actually being analysed. Currently only so-called 'outgrowth endothel ial cells' (or 'late' EPCs) are known to uniformly give origin to functional endotheliocytes. Indeed, CD34 or CD133 and alone or in different combinations (often with KDR) are the most popular markers used to define 'circulating EPCs'. This popularity stems from initial reports showing that CD34+/KDR+ cells could form endothelium-like cells in vitro [ 4, 109]. Although many studies have employed $\mathrm{CD} 34+/ \mathrm{CD} 133+/ \mathrm{KDR}+$ cells as their definition of 'true EPCs' their ability to generate endothelial cells has never been 
reliably proved. Furthermore, these cell populations probably represents a subset of CD45+ haematopoietic progenitors but do not form endothelial cells in vitro [110]. Inclusion of any additional markers in the definition of 'EPC' may hamper a holistic approach towards EPC analysis even further and should only be based on robust data confirming the functional identity of the cells analysed.

The problem with the identification of functional EPCs is also present with approached based on cell culture. For example, markers previously used to prove endothelial identity of putative progenitors, such as CD31, lectin binding or LDL accumulation are now known to be non-specific for the endothelial lineage, but also characteristic for cells of haematopoietic origin] [ 111,112$]$. In fact, the majority of so called 'early' EPCs represent populations of monocytes and lymphocytes which co-express 'endothelial' markers and possess some degree of angiogenic capacity [ 36]. This reemphasises that the initiation of any new clinically-relevant study on EPCs should only be based on clear understanding of type of cells being analysed.

\section{Conclusion}

Since the discovery of EPCs, there has been a rapid proliferation of research data on the relation of EPC to cardiovascular risk, pathology and treatment. So far, EPCs have been implicated in the whole cardiovascular disease process, and many conventional therapies have been shown to alter EPC number and function. More recently, attempts to utilise the clinical potential of EPCs such as in the form of CD34-antibody coated stents, has been attempted. Further challenges will be to develop simple techniques to measure EPCs numbers and function accurately and quickly, as these cells may help determine cardiac risk and outcomes for patients with heart disease.

\section{Abbreviations}

- ACS:

acute coronary syndrome

- AMI:

acute myocardial infarction

- BMS:

bare-metal stents

- CAD:

coronary artery disease

- CEC:

circulating endothelial cells

- CFU-EC:

colony forming unit-endothelial cell

- ECFC:

endothelial colony forming cells

- eNOS:

endothelial nitric oxide synthase

- EPC:

endothelial progenitor cell

- G-CSF:

granulocyte-colony stimulating factor

- HUVEC:

human umbilical vein endothelial cells

- KDR:

kinase insert domain receptor

- NO:

nitric oxide

- PCI:

percutaneous coronary intervention

- TERT:

telomerase reverse transcriptase

- TRF:

telomere repeat-binding factors

- VEGF:

vascular endothelial growth factor

\section{Declarations}

Aurangzeb Siddique, Eduard Shantsila contributed equally to this work.

\section{Competing interests}


AS is funded by a research grant from Orbus Neisch (Orbus Neisch, Netherlands). ES is funded by a research grant of the Heart Failure Association of European Society of Cardiology. CV is UK national coordinating investigator for the TRIAS programme. GL and CV are both investigators in the TRIAS trials.

\section{Authors' contributions}

AS - selected publications for the review, drafted manuscript; ES - participated in the design of the review, drafted manuscript; GYHL - designed manuscripts, edited manuscript; CV - edited manuscript. All authors read and approved the final manuscript.

\section{References}

1. Dong C, Goldschmidt-Clermont PJ. Endothelial progenitor cells: a promising therapeutic alternative for cardiovascular disease. J Interv Cardiol. 2007;20:93-9.

View Article Google Scholar

2. Ross R. Atherosclerosis--an inflammatory disease. N Engl J Med. 1999;340:115-125. View Article Google Scholar

3. Stump MM Jordan GLJ DeBakey ME Halpert B Endothelium grown from circulating blood on isolated intravascular Dacron hub Am J Pathol 1963433613671949804

4. Asahara T, Masuda H, Takahashi T, Kalka C, Pastore C, Silver M, Kearne M, Magner M, Isner JM. Bone marrow origin of endothelial progenitor cells responsible for postnatal vasculogenesis in physiological and pathological neovascularization. Circ Res. 1999;85:221-228.

View Article Google Scholar

5. Bhattacharya V, McSweeney PA, Shi Q, Bruno B, Ishida A, Nash R, Storb RF, Sauvage LR, Hammond WP, $\mathrm{Wu} \mathrm{MH}$. Enhanced endothelialization and microvessel formation in polyester grafts seeded with CD34 (+) bone marrow cells. Blood. 2000;95:581-585.

View Article Google Scholar

6. Gehling UM, Ergun S, Schumacher U, Wagener C, Pantel K, Otte M, Schuch G, Schafhausen P, Mende T, Kilic N, Kluge K, Schäfer B, Hossfeld DK, Fiedler W. In vitro differentiation of endothelial cells from AC133-positive progenitor cells. Blood. 2000;95:3106-3112.

View Article Google Scholar

7. Hu Y, Davison F, Zang Z, Xu Q. Endothelial replacement and angiogenesis in arteriosclerotic lesions of allografts are contributed by circulating progenitor cells. Circulation. 2003;108:3122-3127.

View Article Google Scholar

8. Hill JM, Zalos G, Halcox JP, Schenke WH, Waclawiw MA, Quyyumi AA, Finkel T. Circulating endothelial progenitor cells, vascular function, and cardiovascular risk. N Engl J Med. 2003;348:593-600.

View Article Google Scholar

9. Vasa M, Fichtlscherer S, Aicher A, Adler K, Urbich C, Martin H, Zeiher AM, Dimmeler S. Number and migratory capacity of circulating Endothelial Progenitor Cells inversely correlate with risk factors for coronary artery disease. Circ Res. 2001;89:1-7.

View Article Google Scholar

10. Jie KE, Goossens MH, van Oostrom O, Lilien MR, Verhaar MC. Circulating endothelial progenitor cell levels are higher during childhood than in adult life. Atherosclerosis. 2009;202:345-347.

View Article Google Scholar

11. Schaffer RG, Greene S, Arshi A, Supple G, Bantly A, Moore JS, Parmacek MS, Mohler ER. Effect of acute exercise on endothelial progenitor cells in patients with peripheral arterial disease. Vasc Med. 2006;11:219-226.

View Article Google Scholar

12. Hoetzer GL, Van Guilder Gary GP, Irmiger HM, Keith RS. Aging, exercise, and endothelial progenitor cell clonogenic and migratory capacity in men. J Appl Physiol. 2007;102:847-852.

View Article Google Scholar 
13. Pelliccia F, Pasceri V, Meoni G, Pristipino C, Cianfrocca C, Li X, La Rocca S, Rosano G, Mercuro G, Richichi G. Numbers of endothelial progenitor cells in peripheral blood are similar in younger and older patients with coronary artery disease. Int J Cardiol. 2009;133:277-279.

View Article Google Scholar

14. Chang EI, Loh SA, Ceradini DJ, Chang EI, Lin S, Bastidas N, Aarabi S, Chan DA, Freedman ML, Giaccia AJ, Gurtner GC. Age decreases endothelial progenitor cell recruitment through decreases in hypoxiainducible factor 1 stabilization during ischemia. Circulation. 2007;116:2818-2829.

View Article Google Scholar

15. Laufs U, Werner N, Link A, Endres M, Wassmann S, Jürgens K, Miche E, Böhm M, Nickenig G. Physical Training Increases Endothelial Progenitor Cells, Inhibits Neointima Formation, and Enhances Angiogenesis. Circulation. 2004;109:220-226.

View Article Google Scholar

16. Rauscher FM, Goldschmidt-Clermont PJ, Davis BH, Wang T, Gregg D, Ramaswami P, Pippen AM, Annex BH, Dong C, Taylor DA. Aging, progenitor cell exhaustion, and atherosclerosis. Circulation. 2003;108:457463.

View Article Google Scholar

17. Maisel AS Knowlton KU Fowler P Rearden A Ziegler MG Motulsky HJ Insel PA Michel MC Adrenergic control of circulating lymphocyte subpopulations. Effects of congestive heart failure, dynamic exercise, and terbutaline treatment J Clin Invest 199085462467296446

18. Rehman J, Li J, Parvathaneni L, Karlsson G, Panchal VR, Temm CJ, Mahenthiran J, March KL. Exercise acutely increases circulating endothelial progenitor cells and monocyte-/macrophage-derived angiogenic cells. J Am Coll Cardiol. 2004;43:2314-2318.

View Article Google Scholar

19. Fukai T Siegfried MR Ushio-Fukai M Cheng Y Kojda G Harrison DG Regulation of the vascular extracellular superoxide dismutase by nitric oxide and exercise training J Clin Invest 20001051631 1639300857

20. Vasa M, Fichtlscherer S, Adler K, Aicher A, Martin H, Zeiher AM, Dimmeler S. Increase in circulating endothelial progenitor cells by statin therapy in patients with stable coronary artery disease.

Circulation. 2001;103:2885-2890.

View Article Google Scholar

21. Ito H, Rovira II, Bloom ML, Takeda K, Ferrans VJ, Quyyumi AA, Finkel T. Endothelial progenitor cells as putative targets for angiostatin. Cancer Res. 1999;59:5875-5877.

View Article Google Scholar

22. Li D, Yang B, Mehta JL. Ox-LDL induces apoptosis in human coronary artery endothelial cells: role of PKC, PTK, bcl-2, and Fas. Am J Physiol. 1998;275:568-576.

View Article Google Scholar

23. Chen JZ, Zhang FR, Tao OM, Wang XX, Zhu JH, Zhu JH. Number and activity of endothelial progenitor cells from peripheral blood in patients with hypercholesterolaemia. Clinical Science. 2004;107:273-280.

View Article Google Scholar

24. Chavakis E, Dernbach E, Hermann C, Mondorf UF, Zeiher AM, Dimmeler S. Oxidized LDL inhibits VEGFinduced endothelial cell migration by an inhibitory effect on the Akt/eNOS pathway. Circulation. 2001;103:2102-2107.

View Article Google Scholar

25. Morales-Ruiz M, Fulton D, Sowa G, Languino LR, Fujio Y, Walsh K, Sessa WC. Vascular endothelial growth factor-stimulated actin reorganization and migration of endothelial cells is regulated via the serine/threonine kinase Akt. Circ Res. 2000;86:892-896.

View Article Google Scholar 
26. Tepper OM, Galiano RD, Capla JM, Kalka C, Gagne PJ, Jacobowitz GR, Levine JP, Gurtner GC. Human endothelial progenitor cells from type 2 diabetics exhibit impaired proliferation, adhesion, and incorporation into vascular structures. Circulation. 2002;106:2781-2786.

View Article Google Scholar

27. Ii M, Takenaka H, Asai J, Ibusuki K, Mizukami Y, Maruyama K, Yoon YS, Wecker A, Luedemann C, Eaton E, Silver M, Thorne T, Losordo DW. Endothelial progenitor thrombospondin-1 mediates diabetes-induced delay in reendothelialization following arterial injury. Circ Res. 2006;98:697-704.

View Article Google Scholar

28. Chen YH, Lin SJ, Lin FY, Wu TC, Tsao CR, Huang PH, Liu PL, Chen YL, Chen JW. High Glucose Impairs Early and Late Endothelial Progenitor Cells by Modifying Nitric Oxide-Related but Not Oxidative Stress-Mediated Mechanisms. Diabetes. 2007;56:1559-1568.

View Article Google Scholar

29. Imanishi T, Hano T, Nishio I. Angiotensin II potentiates vascular endothelial growth factor-induced proliferation and network formation of endothelial progenitor cells. Hypertens Res. 2004;27:101-108. View Article Google Scholar

30. Min TQ, Zhu CJ, Xiang WX, Hui ZJ, Peng SY. Improvement in endothelial progenitor cells from peripheral blood by ramipril therapy in patients with stable coronary artery disease. Cardiovasc Drugs Ther. 2004;18:203-9.

View Article Google Scholar

31. Werner N, Kosiol S, Schiegl T, Ahlers P, Walenta K, Link A, Bohm M, Nickenig G. Circulating endothelial progenitor cells and cardiovascular outcomes. N Engl J Med. 2005;353:999-1007.

View Article Google Scholar

32. Kondo T, Hayashi M, Takeshita K, Numaguchi Y, Kobayashi K, Iino S, Inden Y, Murohara T. Smoking cessation rapidly increases circulating progenitor cells in peripheral blood in chronic smokers. Arterioscler Thromb Vasc Biol. 2004;24:1442-7.

View Article Google Scholar

33. Wang XX, Zhu JH, Chen JZ. Effects of Nicotine on the Number and Activity of Circulating Endothelial Progenitor Cells. J Clin Pharmacol. 2004;44:881-889.

View Article Google Scholar

34. Shantsila E, Watson T, Lip GY. Statins and inflammation: reciprocal effectors to endothelial progenitors?. Thromb Res. 2008;123:1-4.

View Article Google Scholar

35. Shantsila E, Watson T, Lip GY. Antioxidant protection: yet another function of endothelial progenitor cells?. J Hum Hypertens. 2007;21:343-6.

View Article Google Scholar

36. Shantsila E, Watson T, Lip GY. Endothelial progenitor cells in cardiovascular disorders. J Am Coll Cardiol. 2007;49:741-52.

View Article Google Scholar

37. Schmidt-Lucke C, Rössig L, Fichtlscherer S, Vasa M, Britten M, Kämper U, Dimmeler S, Zeiher AM.

Reduced number of circulating endothelial progenitor cells predicts future cardiovascular events:

Proof of concept for endogenous vascular repair. Circulation. 2005;111:2981-2987.

View Article Google Scholar

38. Boos CJ, Blann AD, Lip GYH. Circulating endothelial cells in cardiovascular disease. J Am Coll Cardiol. 2006;48:1538-47.

View Article Google Scholar

39. Chong AY, Blann AD, Patel J, Freestone B, Hughes E, Lip GY. Endothelial dysfunction and damage in congestive heart failure: relation of flow-mediated dilation to circulating endothelial cells, plasma indexes of endothelial damage, and brain natriuretic peptide. Circulation. 2004;110:1794-1798.

View Article Google Scholar 
40. Makin AJ, Blann AD, Chung NA, Silverman SH, Lip GY. Assessment of endothelial damage in atherosclerotic vascular disease by quantification of circulating endothelial cells. Eur Heart J. 2004;25:371-376.

View Article Google Scholar

41. Thum T, Tsikas D, Stein S, Schultheiss M, Eigenthaler M, Anker SD, Poole-Wilson PA, Ertl G, Bauersachs J. Suppression of Endothelial Progenitor Cells in Human Coronary Artery Disease by the Endogenous Nitric Oxide Synthase Inhibitor Asymmetric Dimethylarginine. J Am Coll Cardiol. 2005;46:1693-1701. View Article Google Scholar

42. Kunz GA, Liang G, Cuculi F, Gregg D, Vata KC, Shaw LK, Goldschmidt-Clermont PJ, Dong C, Taylor DA, Peterson ED. Circulating endothelial progenitor cells predict coronary artery disease severity. Am Heart J. 2006;152:190-5.

View Article Google Scholar

43. Güven H, Shepherd RM, Bach RG, Capoccia BJ, Link DC. The number of endothelial progenitor cell colonies in the blood is increased in patients with angiographically significant coronary artery disease. J Am Coll Cardiol. 2006;48:1579-87.

View Article Google Scholar

44. Werner N, Wassmann S, Ahlers P, Schiegl T, Kosiol S, Link A, Walenta K, Nickenig G. Endothelial progenitor cells correlate with endothelial function in patients with coronary artery disease. Basic Res Cardiol. 2007;102:565-71.

View Article Google Scholar

45. Wojakowski W, Tendera M, Michałowska A, Majka M, Kucia M, Maślankiewicz K, Wyderka R, Ochała A, Ratajczak MZ. Mobilization of CD34/CXCR4+, CD34/CD117+, c-met+ stem cells, and mononuclear cells expressing early cardiac, muscle, and endothelial markers into peripheral blood in patients with acute myocardial infarction. Circulation. 2004;110:3213-20.

View Article Google Scholar

46. Massa M, Rosti V, Ferrario M, Campanelli R, Ramajoli I, Rosso R, De Ferrari GM, Ferlini M, Goffredo L, Bertoletti A, Klersy C, Pecci A, Moratti R. Increased circulating hematopoietic and endothelial progenitor cells in the early phase of acute myocardial infarction. Blood. 2005;105:199-206.

View Article Google Scholar

47. Leone AM, Rutella S, Bonanno G, Abbate A, Rebuzzi AG, Giovannini S, Lombardi M, Galiuto L, Liuzzo G, Andreotti F, Lanza GA, Contemi AM, Leone G, Crea F. Mobilization of bone marrow-derived stem cells after myocardial infarction and left ventricular function. Eur Heart J. 2005;26:1196-1204.

View Article Google Scholar

48. Shintani S, Murohara T, Ikeda H, Ueno T, Honma T, Katoh A, Sasaki K, Shimada T, Oike Y, Imaizumi T. Mobilization of endothelial progenitor cells in patients with acute myocardial infarction. Circulation. 2001;103:2776-9.

View Article Google Scholar

49. Numaguchi Y, Sone T, Okumura K, Ishii M, Morita Y, Kubota R, Yokouchi K, Imai H, Harada M, Osanai H, Kondo T, Murohara T. The impact of the capability of circulating progenitor cell to differentiate on myocardial salvage in patients with primary acute myocardial infarction. Circulation. 2006;114:I114-9. View Article Google Scholar

50. Gaspardone A Menghini F Mazzuca V Skossyreva O Barbato G de Fabritiis P Progenitor cell mobilisation in patients with acute and chronic coronary artery disease Heart 20069225341860756

51. Wojakowski W, Kucia M, Kaźmierski M, Ratajczak MZ. Circulating progenitor cells in stable coronary heart disease and acute coronary syndromes: relevant reparatory mechanism?. Heart. 2008;94:27-33. View Article Google Scholar

52. Valgimigli M, Rigolin GM, Fucili A, Porta MD, Soukhomovskaia O, Malagutti P, Bugli AM, Bragotti LZ, Francolini G, Mauro E, Castoldi G, Ferrari R. CD34+ and endothelial progenitor cells in patients with various degrees of congestive heart failure. Circulation. 2004;110:1209-12.

View Article Google Scholar 
53. Nonaka-Sarukawa M, Yamamoto K, Aoki H, Nishimura Y, Tomizawa H, Ichida M, Eizawa T, Muroi K, Ikeda U, Shimada K. Circulating endothelial progenitor cells in congestive heart failure. Int J Cardiol. 2007;119:344-8.

View Article Google Scholar

54. Landmesser U, Engberding N, Bahlmann FH, Schaefer A, Wiencke A, Heineke A, Spiekermann S, HilfikerKleiner D, Templin C, Kotlarz D, Mueller M, Fuchs M, Hornig B, Haller H, Drexler H. Statin-induced improvement of endothelial progenitor cell mobilization, myocardial neovascularization, left ventricular function, and survival after experimental myocardial infarction requires endothelial nitric oxide synthase. Circulation. 2004;110:1933-9.

View Article Google Scholar

55. Michowitz Y Goldstein E Wexler D Sheps D Keren G George J Circulating endothelial progenitor cells and clinical outcome in patients with congestive heart failure Heart 2007931046501955007

56. Kipshidze N, Dangas G, Tsapenko M, Moses J, Leon MB, Kutryk M, Serruys P. Role of the endothelium in modulating neointimal formation: vasculoprotective approaches to attenuate restenosis after percutaneous coronary interventions. J Am Coll Cardiol. 2004;44:733-9.

View Article Google Scholar

57. Werner N, Junk S, Laufs U, Link A, Walenta K, Bohm M, Nickenig G. Intravenous transfusion of endothelial progenitor cells reduces neointima formation after vascular injury. Circ Res. 2003;93:17-24. View Article Google Scholar

58. Blindt R, Vogt F, Astafieva I, Fach C, Hristov M, Krott N, Seitz B, Kapurniotu A, Kwok C, Dewor M, Bosserhoff AK, Bernhagen J, Hanrath P, Hoffmann R, Weber C. A novel drug-eluting stent coated with an integrin-binding cyclic Arg-Gly-Asp peptide inhibits neointimal hyperplasia by recruiting endothelial progenitor cells. J Am Coll Cardiol. 2006;47:1786-95.

View Article Google Scholar

59. Kang HJ, Kim HS, Zhang SY, Park KW, Cho HJ, Koo BK, Kim YJ, Soo Lee D, Sohn DW, Han KS, Oh BH, Lee MM, Park YB. Effects of intracoronary infusion of peripheral blood stem-cells mobilised with granulocyte-colony stimulating factor on left ventricular systolic function and restenosis after coronary stenting in myocardial infarction: the MAGIC cell randomised clinical trial.Lancet. 2004;363:751-6.

View Article Google Scholar

60. Kang HJ, Lee HY, Na SH, Chang SA, Park KW, Kim HK, Kim SY, Chang HJ, Lee W, Kang WJ, Koo BK, Kim YJ, Lee DS, Sohn DW, Han KS, Oh BH, Park YB, Kim HS. Differential effect of intracoronary infusion of mobilized peripheral blood stem cells by granulocyte colony-stimulating factor on left ventricular function and remodeling in patients with acute myocardial infarction versus old myocardial infarction: the MAGIC Cell-3-DES randomized, controlled trial. Circulation. 2006;114:I145-51.

View Article Google Scholar

61. Lim SY, Kim YS, Ahn Y, Jeong MH, Rok LS, Kim JH, Kim KH, Park HW, Kim W, Cho JG, Park JC, Kang PM, Schwartz RS, Kang JC. The effects of granulocyte-colony stimulating factor in bare stent and sirolimus-eluting stent in pigs following myocardial infarction. Int J Cardiol. 2007;118:304-11. View Article Google Scholar

62. Schober A, Hoffmann R, Oprée N, Knarren S, Iofina E, Hutschenreuter G, Hanrath P, Weber C. Peripheral CD34+ cells and the risk of in-stent restenosis in patients with coronary heart disease. Am J Cardiol. 2005;96:1116-22.

View Article Google Scholar

63. Cho HJ, Kim TY, Cho HJ, Park KW, Zhang SY, Kim JH, Kim SH, Hahn JY, Kang HJ, Park YB, Kim HS. The effect of stem cell mobilization by granulocyte-colony stimulating factor on neointimal hyperplasia and endothelial healing after vascular injury with bare-metal versus paclitaxel-eluting stents. J Am Coll Cardiol. 2006;48:366-74.

View Article Google Scholar

64. Tuleta I, Skowasch D, Peuster M, Nickenig G, Bauriedel G. Cells of primarily extravascular origin in neointima formation following stent implantation: coordinated expression of endothelial progenitor, 
dendritic and neural crest-derived cells. Cardiology. 2008;110:199-205.

View Article Google Scholar

65. Inoue T, Masataka S, Yutaka H, Sohma R, Fukuda D, Uchida T, Shimizu M, Komoda H, Node K.

Mobilization of CD34 positive bone marrow-derived cells after coronary stent implantation: impact on restenosis. Circulation. 2007;115:553-561.

View Article Google Scholar

66. Butzal M, Loges S, Schweizer M, Fischer U, Gehling UM, Hossfeld DK, Fiedler W. Rapamycin inhibits proliferation and differentiation of human endothelial progenitor cells in vitro. Exp Cell Res. 2004;300:65-71.

View Article Google Scholar

67. Gautam K, Lee MS. Stent thrombosis with drug-eluting stents: a re-examination of the evidence. Catheter Cardiovasc Interv. 2007;69:782-9.

View Article Google Scholar

68. Matsuo Y, Imanishi T, Hayashi Y, Tomobuchi Y, Kubo T, Hano T, Akasaka T. The Effect of senescence of endothelial progenitor cells on in-stent restenosis in patients undergoing coronary stenting. Intern Med. 2006;45:581-7.

View Article Google Scholar

69. Smadja DM, Godier A, Susen S, Packard RR, Fabiani JN, Aiach M, Gaussem P. Endothelial progenitor cells are selectively mobilised immediately after coronary artery bypass grafting or valve surgery. Thromb Haemost. 2009;101:983-5.

View Article Google Scholar

70. Choi YH, Neef K, Reher M, Liakopoulos OJ, Zeriouh M, Wittwer T, Stamm C, Madershahian N, Teschendorf $\mathrm{P}$, Wahlers $\mathrm{T}$. The influence of pre-operative risk on the number of circulating endothelial progenitor cells during cardiopulmonary bypass. Cytotherapy. 2010;12:79-87.

View Article Google Scholar

71. Walter DH, Rittig K, Bahlmann FH, Kirchmair R, Silver M, Murayama T, Nishimura H, Losordo DW, Asahara T, Isner JM, Walter DH, Rittig K, Bahlmann FH. Statin Therapy Accelerates Reendothelialization. Circulation. 2002;105:3017-24.

View Article Google Scholar

72. Hristov M, Fach C, Becker C, Heussen N, Liehn EA, Blindt R, Hanrath P, Weber C. Reduced numbers of circulating endothelial progenitor cells in patients with coronary artery disease associated with longterm statin treatment. Atherosclerosis. 2007;192:413-20.

View Article Google Scholar

73. Chong AY, Blann AD, Patel J, Freestone B, Hughes E, Lip GY. Endothelial dysfunction and damage in congestive heart failure: relation of flow-mediated dilation to circulating endothelial cells, plasma indexes of endothelial damage, and brain natriuretic peptide. Circulation. 2004;110:1794-1798.

View Article Google Scholar

74. Deschaseaux F, Selmani Z, Falcoz PE, Mersin N, Meneveau N, Penfornis A, Kleinclauss C, Chocron S, Etievent JP, Tiberghien P, Kantelip JP, Davani S. Two types of circulating endothelial progenitor cells in patients receiving long term therapy by HMG-CoA reductase inhibitors. Eur J Pharmacol.

2007;562:111-8.

View Article Google Scholar

75. Bahlmann FH, de Groot K, Mueller O, Hertel B, Haller H, Fliser D. Stimulation of Endothelial Progenitor Cells A New Putative Therapeutic Effect of Angiotensin II Receptor Antagonists. Hypertension. 2005;45:526-.

View Article Google Scholar

76. Wang CH, Verma S, Hsieh IC, Chen YJ, Kuo LT, Yang NI, Wang SY, Wu MY, Hsu CM, Cheng CW, Cherng WJ. Enalapril increases ischemia-induced endothelial progenitor cell mobilization through manipulation of the CD26 system. J Mol Cell Cardiol. 2006;41:34-43.

View Article Google Scholar 
77. Werner C, Kamani CH, Gensch C, Böhm M, Laufs U. The peroxisome proliferator-activated receptorgamma agonist pioglitazone increases number and function of endothelial progenitor cells in patients with coronary artery disease and normal glucose tolerance. Diabetes. 2007;56:2609-15.

View Article Google Scholar

78. Haffner SM, Greenberg AS, Weston WM, Chen H, Williams K, Freed MI. Effect of rosiglitazone treatment on nontraditional markers of cardiovascular disease in patients with type 2 diabetes mellitus.

Circulation. 2002;106:679-684.

View Article Google Scholar

79. Verma S, Kuliszewski MA, Li SH, Szmitko PE, Zucco L, Wang CH, Badiwala MV, Mickle DA, Weisel RD, Fedak PW, Stewart DJ, Kutryk MJ. C-Reactive Protein Attenuates Endothelial Progenitor Cell Survival, Differentiation, and Function Further Evidence of a Mechanistic Link Between C-Reactive Protein and Cardiovascular Disease. Circulation. 2004;109:2058-67.

View Article Google Scholar

80. Han JK, Lee HS, Yang HM, Hur J, Jun SI, Kim JY, Cho CH, Koh GY, Peters JM, Park KW, Cho HJ, Lee HY, Kang HJ, Oh BH, Park YB, Kim HS. Peroxisome proliferator-activated receptor-delta agonist enhances vasculogenesis by regulating endothelial progenitor cells through genomic and nongenomic activations of the phosphatidylinositol 3-kinase/Akt pathway. Circulation. 2008;118:1021-1033. View Article Google Scholar

81. He T Lu T d'Uscio LV Lam CF Lee HC Katusic ZS Angiogenic function of prostacyclin biosynthesis in human endothelial progenitor cells Circ Res 200810380882664088

82. Strehlow K, Werner N, Berweiler J, Link A, Dirnagl U, Priller J, Laufs K, Ghaeni L, Milosevic M, Böhm M, Nickenig G. Estrogen Increases Bone Marrow-Derived Endothelial Progenitor Cell Production and Diminishes Neointima Formation. Circulation. 2003;107:3059-65.

View Article Google Scholar

83. Iwakura A, Luedemann C, Shastry S, Hanley A, Kearney M, Aikawa R, Isner JM, Asahara T, Losordo DW. Estrogen-mediated, endothelial nitric oxide synthase-dependent mobilization of bone marrow-derived endothelial progenitor cells contributes to reendothelialization after arterial injury. Circulation. 2003;108:3115-21.

View Article Google Scholar

84. Bourassa MG, Wilson JW, Detre KM, Kelsey SF, Robertson T, Passamani ER. Long-term follow-up of coronary angioplasty: the 1977-1981 National Heart, Lung, and Blood Institute registry. Eur Heart J. 1989;10:36-41.

View Article Google Scholar

85. McFadden EP, Stabile E, Regar E, Cheneau E, Ong AT, Kinnaird T, Suddath WO, Weissman NJ, Torguson R, Kent KM, Pichard AD, Satler LF, Waksman R, Serruys PW. Late thrombosis in drug-eluting coronary stents after discontinuation of antiplatelet therapy. Lancet. 2004;364:1519-1521.

View Article Google Scholar

86. Ong AT, McFadden E, Regar E, de Jaegere PP, van Domburg RT, Serruys PW. Late angiographic stent thrombosis (LAST) events with drug-eluting stents. J Am Coll Cardiol. 2005;45:2088-2092.

View Article Google Scholar

87. Losordo DW, Isner JM, Diaz-Sandoval LJ. Endothelial Recovery The Next Target in Restenosis Prevention. Circulation. 2003;107:2635-37.

View Article Google Scholar

88. Kutryk MJ, Kuliszewski MA. In vivo endothelial progenitor cell seeding for the accelerated endothelialization of endovascular devices. Am J Cardiol. 2003;92:94-98.

View Article Google Scholar

89. Aoki J, Serruys PW, van Beusekom H. Endothelial progenitor cell capture by stents coated with antibody against CD34: the HEALING-FIM (Healthy Endothelial Accelerated Lining Inhibits Neointimal Growth-First In Man) Registry. J Am Coll Cardiol. 2005;45:1574-9.

View Article Google Scholar 
90. Zhou Z, Shi S, Song M, Huang H, Chen K, Mi J, Li L, Chen G, Hou C, Huang G, Zhu C. Development of transgenic endothelial progenitor cell-seeded stents. J Biomed Mater Res A. 2009;91:623-8.

View Article Google Scholar

91. Co M, Tay E, Lee CH, Poh KK, Low A, Lim J, Lim IH, Lim YT, Tan HC. Use of endothelial progenitor cell capture stent (Genous Bio-Engineered R Stent) during primary percutaneous coronary intervention in acute myocardial infarction: intermediate- to long-term clinical follow-up. Am Heart J. 2008;155:12832 .

View Article Google Scholar

92. Miglionico M, Patti G, D'Ambrosio A, Di Sciascio G. Percutaneous coronary intervention utilizing a new endothelial progenitor cells antibody-coated stent: a prospective single-center registry in high-risk patients. Catheter Cardiovasc Interv. 2008;71:600-4.

View Article Google Scholar

93. Klomp M, Beijk MA, Verouden NJ, Tijssen JG, de Winter RJ. Design and rationale of the TRI-stent adjudication study (TRIAS) program. Am Heart J. 2009;158:527-532.

View Article Google Scholar

94. Kawamoto A, Tkebuchava T, Yamaguchi J, Nishimura H, Yoon YS, Milliken C, Uchida S, Masuo O, Iwaguro H, Ma H, Hanley A, Silver M, Kearney M, Losordo DW, Isner JM, Asahara T. Intramyocardial transplantation of autologous endothelial progenitor cells for therapeutic neovascularization of myocardial ischemia. Circulation. 2003;107:461-8.

View Article Google Scholar

95. Ge J Li Y Qian J Shi J Wang Q Niu Y Fan B Liu X Zhang S Sun A Zou Y Efficacy of emergent transcatheter transplantation of stem cells for treatment of acute myocardial infarction (TCT-STAMI) Heart 200692176471861266

96. Meluzín J, Janousek S, Mayer J, Groch L, Hornácek I, Hlinomaz O, Kala P, Panovský R, Prásek J, Kamínek M, Stanícek J, Klabusay M, Korístek Z, Navrátil M, Dusek L, Vinklárková J. Three-, 6-, and 12-month results of autologous transplantation of mononuclear bone marrow cells in patients with acute myocardial infarction. Int J Cardiol. 2008;128:185-92.

View Article Google Scholar

97. Meyer GP, Wollert KC, Lotz J, Steffens J, Lippolt P, Fichtner S, Hecker H, Schaefer A, Arseniev L, Hertenstein B, Ganser A, Drexler H. Intracoronary bone marrow cell transfer after myocardial infarction: eighteen months' follow-up data from the randomized, controlled BOOST (BOne marrOw transfer to enhance ST-elevation infarct regeneration) trial. Circulation. 2006;113:1287-94.

View Article Google Scholar

98. Janssens S, Dubois C, Bogaert J, Theunissen K, Deroose C, Desmet W, Kalantzi M, Herbots L, Sinnaeve P, Dens J, Maertens J, Rademakers F, Dymarkowski S, Gheysens O, Van Cleemput J, Bormans G, Nuyts J, Belmans A, Mortelmans L, Boogaerts M, Werf F Van de. Autologous bone marrow-derived stem-cell transfer in patients with ST-segment elevation myocardial infarction: double-blind, randomised controlled trial. Lancet. 2006;367:113-21.

View Article Google Scholar

99. Schachinger V, Erbs S, Elsasser A, Haberbosch W, Hambrecht R, Holschermann H, Yu J, Corti R, Mathey DG, Hamm CW, Suselbeck T, Werner N, Haase J, Neuzner J, Germing A, Mark B, Assmus B, Tonn T, Dimmeler S, Zeiher AM. Improved clinical outcome after intracoronary administration of bone-marrow-derived progenitor cells in acute myocardial infarction: final 1-year results of the REPAIR-AMI trial. Eur Heart J. 2006;27:2775-83.

View Article Google Scholar

100. Mocini D, Staibano M, Mele L, Giannantoni P, Menichella G, Colivicchi F, Sordini P, Salera P, Tubaro M, Santini M. Autologous bone marrow mononuclear cell transplantation in patients undergoing coronary artery bypass grafting. Am Heart J. 2006;151:192-7.

View Article Google Scholar

101. Tse HF, Kwong YL, Chan JK, Lo G, Ho CL, Lau CP. Angiogenesis in ischaemic myocardium by intramyocardial autologous bone marrow mononuclear cell implantation. Lancet. 2003;361:47-9. View Article Google Scholar 
102. Losordo DW, Schatz RA, White CJ, Udelson JE, Veereshwarayya V, Durgin M, Poh KK, Weinstein R, Kearney M, Chaudhry M, Burg A, Eaton L, Heyd L, Thorne T, Shturman L, Hoffmeister P, Story K, Zak V, Dowling D, Traverse JH, Olson RE, Flanagan J, Sodano D, Murayama T, Kawamoto A, Kusano KF, Wollins J, Welt F, Shah P, Soukas P, Asahara T, Henry TD. Intramyocardial transplantation of autologous CD34+ stem cells for intractable angina: a phase I/IIa double-blind, randomized controlled trial. Circulation. 2007;115:3165-72.

View Article Google Scholar

103. Assmus B, Honold J, Schachinger V, Britten MB, Fischer-Rasokat U, Lehmann R, Teupe C, Pistorius K, Martin H, Abolmaali ND, Tonn T, Dimmeler S, Zeiher AM. Transcoronary transplantation of progenitor cells after myocardial infarction. N Engl J Med. 2006;355:1222-32.

View Article Google Scholar

104. Bartunek J, Vanderheyden M, Vandekerckhove B, Mansour S, De Bruyne B, De Bondt P, Van Haute I, Lootens N, Heyndrickx G, Wijns W. Intracoronary injection of CD133-positive enriched bone marrow progenitor cells promotes cardiac recovery after recent myocardial infarction: feasibility and safety. Circulation. 2005;112:I178-83.

View Article Google Scholar

105. Erbs S, Linke A, Adams V, Lenk K, Thiele H, Diederich KW, Emmrich F, Kluge R, Kendziorra K, Sabri O, Schuler G, Hambrecht R. Transplantation of blood-derived progenitor cells after recanalization of chronic coronary artery occlusion: first randomized and placebo-controlled study. Circ Res. 2005;97:756-62.

View Article Google Scholar

106. Choi JH, Hur J, Yoon CH, Kim JH, Lee CS, Youn SW, Oh IY, Skurk C, Murohara T, Park YB, Walsh K, Kim HS. Augmentation of therapeutic angiogenesis using genetically modified human endothelial progenitor cells with altered glycogen synthase kinase-3beta activity. J Biol Chem. 2004;279:49430-8. View Article Google Scholar

107. Akita T, Murohara T, Ikeda H, Sasaki K, Shimada T, Egami K, Imaizumi T. Hypoxic preconditioning augments efficacy of human endothelial progenitor cells for therapeutic neovascularization. Lab Invest. 2003;83:65-73.

View Article Google Scholar

108. Hirschi KK, Ingram DA, Yoder MC. Assessing identity, phenotype, and fate of endothelial progenitor cells. Arterioscler Thromb Vasc Biol. 2008;28:1584-95.

View Article Google Scholar

109. Shi Q, Rafii S, Wu MH, Wijelath ES, Yu C, Ishida A, Fujita Y, Kothari S, Mohle R, Sauvage LR, Moore MA, Storb RF, Hammond WP. Evidence for circulating bone marrow-derived endothelial cells. Blood. 1998;92:362-7.

View Article Google Scholar

110. Case J, Mead LE, Bessler WK, Prater D, White HA, Saadatzadeh MR, Bhavsar JR, Yoder MC, Haneline LS, Ingram DA. Human CD34+AC133+VEGFR-2+ cells are not endothelial progenitor cells but distinct, primitive hematopoietic progenitors. Exp Hematol. 2007;35:1109-18.

View Article Google Scholar

111. Yoder MC Mead LE Prater D Krier TR Mroueh KN Li F Krasich R Temm CJ Prchal JT Ingram DA Redefining endothelial progenitor cells via clonal analysis and hematopoietic stem/progenitor cell principals Blood 2007109180191801067

112. Timmermans F, Van Hauwermeiren F, De Smedt M, Raedt R, Plasschaert F, De Buyzere ML, Gillebert TC, Plum J, Vandekerckhove B. Endothelial outgrowth cells are not derived from CD133+ cells or CD45+ hematopoietic precursors. Arterioscler Thromb Vasc Biol. 2007;27:1572-9.

View Article Google Scholar

113. Heiss C, Keymel S, Niesler U, Ziemann J, Kelm M, Kalka C. Impaired progenitor cell activity in agerelated endothelial dysfunction. J Am Coll Cardiol. 2005;45:1441-48.

View Article Google Scholar 
114. Dimmeler S Aicher A Vasa M Mildner-Rihm C Adler K Tiemann M Rütten H Fichtlscherer S Martin $\mathrm{H}$ Zeiher AM HMG-CoA reductase inhibitors (statins) increase endothelial progenitor cells via the PI 3-kinase/Akt pathway J Clin Invest 2001108391397209365

115. Landmesser U, Bahlmann F, Mueller M, Spiekermann S, Kirchhoff N, Schulz S, Manes C, Fischer D, de Groot K, Fliser D, Fauler G, März W, Drexler H. Simvastatin versus ezetimibe: pleiotropic and lipidlowering effects on endothelial function in humans. Circulation. 2005;111:2356-63.

View Article Google Scholar

116. Pistrosch F, Herbrig K, Oelschlaegel U, Richter S, Passauer J, Fischer S, Gross P. PPARgamma-agonist rosiglitazone increases number and migratory activity of cultured endothelial progenitor cells. Atherosclerosis. 2005;183:163-7.

View Article Google Scholar

117. Strauer BE, Brehm M, Zeus T, Köstering M, Hernandez A, Sorg RV, Kögler G, Wernet P. Repair of infarcted myocardium by autologous intracoronary mononuclear bone marrow cell transplantation in humans. Circulation. 2002;106:1913-8.

View Article Google Scholar

118. Schächinger V, Assmus B, Britten MB, Honold J, Lehmann R, Teupe C, Abolmaali ND, Vogl TJ, Hofmann WK, Martin H, Dimmeler S, Zeiher AM. Transplantation of progenitor cells and regeneration enhancement in acute myocardial infarction: final one-year results of the TOPCARE-AMI Trial. J Am Coll Cardiol. 2004;44:1690-9.

View Article Google Scholar

119. Ruan W, Pan CZ, Huang GQ, Li YL, Ge JB, Shu XH. Assessment of left ventricular segmental function after autologous bone marrow stem cells transplantation in patients with acute myocardial infarction by tissue tracking and strain imaging. Chin Med J. 2005;118:1175-81.

View Article Google Scholar

120. Strauer BE, Brehm M, Zeus T, Bartsch T, Schannwell C, Antke C, Sorg RV, Kögler G, Wernet P, Müller HW, Köstering M. Regeneration of human infarcted heart muscle by intracoronary autologous bone marrow cell transplantation in chronic coronary artery disease: the IACT Study. J Am Coll Cardiol. 2005;46:1651-8.

View Article Google Scholar

121. Hendrikx M, Hensen K, Clijsters C, Jongen H, Koninckx R, Bijnens E, Ingels M, Jacobs A, Geukens R, Dendale P, Vijgen J, Dilling D, Steels P, Mees U, Rummens JL. Recovery of regional but not global contractile function by the direct intramyocardial autologous bone marrow transplantation: results from a randomized controlled clinical trial. Circulation. 2006;114:I101- .

View Article Google Scholar

122. Schächinger V, Erbs S, Elsässer A, Haberbosch W, Hambrecht R, Hölschermann H, Yu J, Corti R, Mathey DG, Hamm CW, Süselbeck T, Assmus B, Tonn T, Dimmeler S, Zeiher AM. Intracoronary bone marrow-derived progenitor cells in acute myocardial infarction. N Engl J Med. 2006;355:1210-21.

View Article Google Scholar 